\title{
Defining EThNiCity in a CUltural AND Socio-Legal ConteXt: The CASE OF SCOTTISH GYPSY/TRAVELLERS
}

\author{
Colin Clark
}

\section{INTRODUCTION}

In the summer of 2001 the Equal Opportunities Committee of the Scottish Parliament published its Inquiry into Gypsy Travellers and Public Sector Policies (Scottish Parliament 2001a/b). The inquiry had started in the summer of 2000 after various agencies and Scottish Gypsy/Travellers gave evidence indicating that anti-Gypsy/Traveller racism and social exclusion were serious issues facing the community in post-devolution Scotland. The Equal Opportunities Committee had three main goals in conducting this inquiry (Scottish Parliament 2001a, pp. 4-5):

1) To examine how public sector policies relate to the minority group of travelling people, in particular services provided by local authorities (site management, social work services and educational support) and others (health boards and the police);

2) To hear evidence from the travelling people community and from the agencies who interact with them;

3) To report and make recommendations as appropriate following the inquiry.

Written and oral evidence was gathered from October 2000 onwards from a number of sources including Scottish Gypsy/Travellers, service providers, 
policy-makers, academics and voluntary sector agencies. Upon publication in 2001, there was much praise for the report, including from the US State department, and the thirty-seven recommendations that were made (Scottish Parliament 2002). For the purposes of this paper the most significant of the thirty-seven was recommendation number two (Scottish Parliament 2001a, p. 7 - my emphasis):

All legislation and policies should be framed on the understanding that Gypsy Travellers have distinct ethnic characteristics and should therefore be regarded as an ethnic group, until such time as a court decision is made on recognition as a racial group under the Race Relations Act 1976.

It is this recommendation that addresses the fact that although under the Race Relations Act 1976 (as amended 2000) English Romani Gypsies and Irish Travellers are protected as minority ethnic groups, Scottish Gypsy/Travellers are not protected in the same way. The simple reason for this is that no legal test case has yet, as of July 2005, been decided by a court of law and thus a court decision on a relevant case has obviously not been forthcoming. Although largely regarded as being 'only a matter of time' before such recognition occurs, it is this continued lack of clarification that currently leaves Scottish Gypsy/Travellers in a twilight zone of legal uncertainty and confused 'ethnic' status. ${ }^{1}$ In other words, the case literally still needs to be made in a court of law that Scottish Gypsy/Travellers do constitute an ethnic minority group in the eyes of the Mandla $v$ Dowell Lee criteria and the various race relations legislation. The central aim of this paper is to investigate what is actually involved in making this legal case for Scottish Gypsy/Traveller ethnicity and speculatively assessing if such a case might stand up in court.

${ }^{I}$ At the time of writing, the Scottish Executive is re-visiting the 2001 Enquiry and evidence has recently been given by young Scottish Gypsy/Travellers on what has changed and stayed the same for them since 2001. The minutes of the session on Gypsies and Travellers of the Equal Opportunities Committee of the Scottish Parliament on 21/6/05 can be accessed at: http://www.scottish.parliament.uk/business/committees/equal/or-05/eo05-

1002.htm\#Col1013. In another recent development it has been announced that the Scottish Executive will spend up to $£ 3$ million pounds over three years upgrading existing Gypsy/Traveller sites across Scotland (June 2005): http://news.bbc.co.uk/1/hi/scotland/2781359.stm. 


\section{WHAT IS ETHNICITY?}

Before proceeding some comments should be made on what ethnicity can mean. The concept of ethnicity has a long and well-developed history in Europe and beyond (Barker 1981; Barth 1969; Fredrickson 2002; Jenkins 1999) and its growth in importance in the Twentieth and Twenty-First Century is attributable to the post-war redundancy of 'race' as an explanatory concept both within the natural sciences and social sciences. As Miles and Brown have summarised (2003, p. 89 - my emphasis):

In Europe, North America, and Australia, the idea of 'race' is now usually (though not exclusively) used to differentiate collectivities distinguished by skin colour, so that 'races' are either 'black' or 'white' but never 'big-eared' and 'small-eared'. The fact that only certain physical characteristics are signified to define 'races' in specific circumstances indicates that we are investigating not a given, natural division of the world's population, but the application of historically and culturally specific meanings to the totality of human physiological variation. This is made equally evident by historical evidence that records that certain populations have been categorised as different 'races' at different historical times and in different places. Thus, the use of the word 'race' to label groups so distinguished by some combination of phenotypical and cultural attributes is one moment in the ongoing social construction of reality: 'races' are socially imagined rather than biological realities.

Although 'race' had been deemed an inappropriate explanatory tool by the international community as well as the academic community, there was a continued need to make sense of the obvious cultural, social, and political 'differences' between groups that had previously been seen as 'racially' distinct. To be sure, these did not just disappear and stop being discussed. These differences could be based on any one of a whole range of characteristics within what we might call 'cultural' (nationality, culture, language, religion, perceived racial background) and usually they were based on a complex combination or fusion of all of them. ${ }^{2}$ In particular there was a ${ }^{2}$ For example, this idea of Scottish Gypsy/Traveller 'cultural difference' runs
throughout a recent newspaper interview with the singer and storyteller Sheila 
need to analyse the tensions and the advantages and disadvantages that seemed to be almost inevitably associated with these differences. Thus, with 'race' deemed inappropriate to explain these tensions, 'ethnicity' filled an analytical gap. Some authors suggest that 'ethnicity' is really a 'politically correct' term for what we used to call 'race' and, in reality, little of substance has changed except the language and terms we now use (Miles and Brown 2003 , p. 93). This is an extreme view but one with some support. What we can say is that in Britain 'ethnicity' took on both an academic and a legal importance, although the difference between legalistic and academic definitions is more a question of emphasis than essence. ${ }^{3}$ In particular, ethnicity became the key category within the Race Relations Act (1976) (as amended 2000). The matter of what constitutes ethnicity was given definitive legal consideration and scrutiny by the House of Lords in the Mandla $v$ Dowell Lee case. In his detailed and worthwhile analysis, Lord Fraser argued:

For a group to constitute an ethnic group in the sense of the 1976 Act, it must, in my opinion, regard itself, and be regarded by others, as a distinct community by virtue of certain characteristics. Some of these characteristics are essential; others are not essential but one or more of them will commonly be found and will help to distinguish the group from the surrounding community. The conditions which appear to me to be essential are these: (1) a long shared history, of which the group is conscious as distinguishing it from other groups, and the memory of which it keeps alive; (2) a cultural tradition of its own, including family and social customs and manners, often but not necessarily associated with religious observance. In addition to those two essential characteristics the following characteristics are, in my opinion, relevant: (3) either a common geographical origin, or descent from a small number

Stewart. As the Dundee Courier and Advertiser journalist, Michael Alexander writes: 'When she was growing up, Sheila always felt "different" from society, and regularly faced persecution from people "frightened" of her culture.' Sheila Stewart then goes on to say 'I was brought up a Traveller. I've always been a Traveller and I'll die a Traveller ... whatever is different, society is frightened of ...' (Alexander 2005, p.6).

${ }^{3}$ See the essays within the edited collection entitled Ethnicity by Hutchinson and Smith (1997) for a comprehensive overview of the academic use of the concept of ethnicity. 
of common ancestors; (4) a common language, not necessarily peculiar to the group; (5) a common literature peculiar to the group; (6) a common religion different from that of neighbouring groups or from the general community surrounding it; (7) being a minority or being an oppressed or a dominant group within a larger community, for example conquered people (say, the inhabitants of England shortly after the Norman conquest) and their conquerors might both be ethnic groups. ([1983] 1 All ER pp. 1066-7). ${ }^{4}$

This judgement, therefore, sets the parameters for any discussion of the specific case of Scottish Gypsy/Travellers and ethnicity in the context of British/Scottish law.

\section{DEBATING ETHNICITY}

The debate regarding Scottish Gypsy/Travellers ${ }^{5}$ and their ethnicity appears somewhat academic, not to say arcane. It could be argued that the more

${ }^{4}$ Full details of the legal arguments outlined by Lord Fraser in the Mandla Vs Dowell Lee case can be found here: http://www.hrcr.org/safrica/equality/Mandla_DowellLee.htm

${ }^{5}$ In this article I tend to use the term 'Gypsy/Traveller' to describe those individuals, families and communities in and outside of Scotland who choose to describe themselves as such and/or as 'Gypsies', 'Travellers', 'Gypsy/Traveller', 'GypsyTraveller', 'Travelling people' etc. It is evident that there are a number of terms that are used by Gypsy/Travellers and non-Gypsy/Travellers to describe the Scottish Gypsy/Traveller community and none of them are politically neutral or uncontested. In the past, such people were honourably known as 'Tinkers' (Vallee 1955) or 'Tinklers' McCormick 1907) until it came to be widely regarded as a pejorative term. Although it must be noted that there is disagreement within the community, the term 'Gypsy/Traveller' is now one of the most widely used terms and is regarded as acceptable to most people who are members of this community, in particular when talking about issues of definition with Non-Gypsy/Travellers (see Dawson 2002). The term is used and endorsed by the Scottish Gypsy/Traveller Association (SGTA) and is also widely used by people who are not members of the community but who work with them, such as Save the Children Fund, The Scottish Parliament and other charitable and public bodies in Scotland. It is also worth noting that during the 1990s the public shift from 'Traveller' to 'Gypsy/Traveller' was made to try to draw a distinction between traditional ethnic Scottish Travellers (Scottish Gypsy/Travellers) 
pressing issue is Gypsy/Traveller social, political and economic disadvantage across a range of key social policy areas and indices in contemporary Scottish society, whether concerned with mortality, morbidity, health, education, employment or social security (Bancroft, Lloyd and Morran 1996; Clark 1999; Clark 2001; Lloyd, Stead, Jordan and Norris 1999; Jordan and Padfield 2003; Smart, Titterton, Clark 2003). Few commentators would dispute this exclusion and disadvantage and it seems that the key debate is how to explain and remedy such exclusion and disadvantage rather than whether it actually exists or not. It bears emphasis that the legal question of Scottish Gypsy/Traveller ethnicity vis-à-vis Mandla v Dowell Lee becomes an issue to be viewed in this wider context. While Mandla v Dowell Lee gives us a specific legal framework for the discussion, it is not at all unconnected from these wider social, economic and political debates.

The relatively common acceptance of Scottish Gypsy/Traveller ethnicity within academic and public policy communities does tend to suggest that Scottish Gypsy/Traveller disadvantage should be explained in terms of not only what Scottish Gypsy/Travellers do but also what is done to them (Clark 2004, pp. 211-213). It suggests that the attitudes and behaviour of nonGypsy/Traveller society (scaldie or flattie society as is talked about within the Scottish Gypsy/Traveller Cant language, see Braid 2002; Dawson and Smith 2001; Hancock 1986; Stewart 2002) may be key problems for Scottish Gypsy/Travellers. This kind of anti-racist analysis is far removed from common opinion on how to explain Scottish Gypsy/Traveller socioeconomic disadvantage. It is evident from sensationalised media reports that some non-Gypsy/Travellers, and certain organisations, continue to blame Scottish Gypsy/Travellers for their situation of relative socio-economic disadvantage as well as their accommodation problems (Nicolson 2005, p. 1; Simpson 2005, p. 1). This false logic of 'blaming the victim' (Murray 1990), especially when they are deemed to fall within the net of so-called 'dangerous classes' (Morris 1994, pp. 16-19), is not new or, indeed, exclusive to only Gypsy/Travellers.

There are different approaches, however, and academics, such as Rebecca McKinney (2003), Elizabeth Jordan (1998) and Judith Okely (2004) have usually approached Scottish Gypsy/Travellers from a very different point of

from newer kinds of English Travellers who were moving to Scotland at that time ('New Age' Travellers). For more on this please refer to Kenrick and Clark (1999, chapter 3) and also Reid (1997, pp. 31-33). 
view. It is noteworthy that the most informative and high quality academic research on Scottish Gypsy/Travellers has been largely or partly ethnographic in character and usually undertaken over a period of many months if not years (Beckett and Bogie 1998; Braid 1997, 2002; Douglas 1985, 1987, 2002; Jordan and Padfield 2003; McKinney 2003; Rehfisch 1958, 1961; Rehfisch and Rehfisch 1975). This in-depth ethnographic approach is, of course, no guarantor of ethnicity, or indeed of 'being right', but it does imply an acceptance of there being an element of important 'cultural stuff' to be examined and analysed. Moreover, the approach of most ethnographers is firmly grounded in the belief that Scottish Gypsy/Travellers possess such 'stuff': a culture, language and social organisation that to various degrees stands them apart from majority settled society. As Rehfisch and Rehfisch (1975, p. 283) have put it, Gypsy/Travellers have held 'tight to values and attitudes which are often in conflict with those of the mass society' and this has been self-evident as 'if they had not done so they would have merged with the flattie group'. In other words, for academic researchers, Gypsy/Travellers constitute a distinct ethnic group and they identify and discuss most of the characteristics raised in the case of Mandla $v$ Dowell Lee (Okely 2004, pp. 3-6). Moreover, they rarely search for other 'non-ethnic' explanations of Scottish Gypsy/Traveller identity (see especially Braid's (1997, 1999, 2002) work). Thus the context for resolving the question of Scottish Gypsy/Traveller ethnicity does involve an unusual and puzzling dialectic: the majority (settled) society tends to regard Scottish Gypsy/Travellers as not constituting an ethnic group ('but they are white?') whilst most academic and policy commentators assume that they are a distinct ethnic group ('they have their own identity, culture and language.').

This is the ethnicity conundrum that we must try to work out. Before attempting to do so, however, a brief note of caution is required. It is crucial to acknowledge that there are sensitivities in such cases where ethnicity is being ascribed to an individual, group or community by the state and its agents. To be sure, the 'imposition' of an 'official' ethnicity or status does not usually occur without political conditions attached to it, as is the case with the Kurds in Iran (Shams 2004). Further, given what happened during the time of the Nazi Third Reich, some caution is to be recommended when thinking of the potential implications and consequences of such ascription (Burleigh and Wippermann 1991; Huttenbach 1991). Essentially, this is where the personal may clash with the political: that is the political recognition of ethnicity may clash with personal understandings or conceptions of who and what one is. This sensitivity on matters of ascription 
logically follows on from related concerns vis-à-vis the many debates on definitions and terminology, that is, what a community chooses to calls itself (see footnote 5). McKinney (2003, pp. 19-20) discusses the issues of ascribing ethnicity in some detail in her article and urges a degree of caution by reminding us, following Blum (2001, p. 98), that ethnic recognition can produce a potential 'protection/threat' corollary: if you are ' $\mathrm{A}$ ' then you are not 'B'. According to McKinney (2003, p. 20), some Gypsy/Travellers are 'overly optimistic' regarding the promises that official legal recognition of their ethnicity might deliver (the end of discrimination?) and for those opposed to being classified in such a way it is about not being thought of as 'foreign' or as a visible ('non-white') 'ethnic minority' which itself can produce a racist problematic. In the context of a 'Scotland for all' and a 'One Scotland, many cultures' approach to social inclusion and multiculturalism it is important to appreciate the sensitivities behind each and every community that together make up such pluralist and collective approaches, including Gypsy/Travellers.

\section{SCOTTISH GYPSY/TRAVELLERS AND ETHNICITY}

It is clear that much of the discourse about Scottish Gypsy/Travellers is very similar to racialised discourses about groups whose 'ethnicity' and experience of racism is widely and unproblematically accepted (Clark and Dearling 2000, pp. 42-44; Maan 1992; McKinney 2003, pp. 27-29). The terms 'ethnicity' and 'ethnic community' have also been used by some Scottish Gypsy/Travellers to make sense of Scottish Gypsy/Traveller 'difference' and identity and their separateness from settled society (Reid 1997, p. 32; McAllister 2005, p. 5). Equally, the term 'racism' is used by some Scottish Gypsy/Travellers to explain perceived anti-Scottish Gypsy/Traveller prejudice and discrimination from settled people (Mark Kennedy, as quoted in Crawford 2003; Scottish Parliament 2000a,b) ${ }^{6}$. Thus

\footnotetext{
${ }^{6}$ I refer here also to the BBC2 TV programme EX's which broadcast a 30 minute documentary on Scottish Gypsy/Travellers on 7 March 1995 entitled 'Tales from the Tarmac'. In a section of this programme a number of people expected at a Gypsy/Traveller wedding in Scotland do not attend as they find out that TV cameras are to be present from the EX's team. The upset groom explains that some people are not attending as they do not want to be identified as Gypsy/Travellers as much of their business is with non-Gypsy/Travellers and they fear their trade and business
} 
there is prima facie evidence to support the argument that Scottish Gypsy/Travellers are an ethnic group who can experience racism (Clarke, Egon and Wake 1998). However the appropriateness of using these terms with reference to the experience of Scottish Gypsy/Travellers remains contested. Even within the broader Scottish Gypsy/Traveller support movement the notions of Scottish Gypsy/Traveller ethnicity and experience of racism can cause intense debate and discussion. Some organisations endorse the use of ethnicity and racism while others remain ambiguous about either or both. ${ }^{7}$ This ambiguity is compounded by the still uncertain legal status of Scottish Gypsy/Travellers in different socio-legal contexts. As alluded to, Scottish Gypsy/Travellers have a different ethnic status in law when compared with both English Romani Gypsies and Irish Travellers. Although the ethnicity of English Gypsies in the context of the Race Relations Act 1976 (as amended 2000) has been accepted post-Dutton, that of Scottish Gypsy/Travellers remains a moot point. ${ }^{8}$ Since August 2000 and

relationships might be jeopardised if they are 'known' to be Gypsy/Travellers. The groom accepts this as a valid reason for some people not attending, despite his upset.

${ }^{7}$ The politics of settled people working with Gypsy/Travellers can be split into three camps at present: firstly, there are organisations which regard their work as essentially charity, and ignore (and therefore implicitly deny) the issue of Gypsy/Traveller ethnicity; secondly, there are those organisations that have taken up the notion of Gypsy/Traveller ethnicity but tend to be reluctant to recognize the existence of anti-Gypsy/Traveller racism; thirdly, there are those organisations which have been founded on the basis of recognising Gypsy/Traveller ethnicity and antiGypsy/Traveller racism. This is not unlike the situation in Ireland, England and Wales and indeed across mainland Europe.

${ }^{8}$ Originally, English Romani Gypsies, but not necessarily Irish Travellers or Scottish Gypsy/Travellers, were protected by the Race Relations Act (1976) since the decision of the Court of Appeal in Commission for Racial Equality -v-Dutton [1989] 1 All ER 306. However, on August 29 2000, Judge Goldstein in his judgement on P. O'Leary and Others -vs- Allied Domecq and Others (NO. CL. 950275-70) confirmed that Irish Travellers were protected as a minority ethnic group by the Race Relations Act 1976. He did not concern himself with Scottish Gypsy/Travellers in this case. What is also interesting to note here is the fact that some cases of anti-Scottish Gypsy/Traveller racism have been taken forward to the courts during the last few years, in cases against either employers or restaurant and pub chains (Okely 1997, p. 236), but they have not lasted the course and gone through the entire legal process so a judgement could be reached on the official status of Scottish Gypsy/Traveller ethnicity, as has been the case in England for English Gypsies and Irish Travellers. Why this is the 
the P. O'Leary \& Others -v-Allied Domecq \& Others court case, Irish Travellers are also now explicitly covered by the Race Relations Act 1976 (as amended 2000). These issues make it necessary to ask whether there are $a$ priori reasons to deny either the ethnicity of Scottish Gypsy/Travellers in Scotland/Britain or their capacity to experience racism: if English Romani Gypsies and Irish Travellers in Britain can, potentially, experience racial discrimination then it would seem reasonable to suggest that Scottish Gypsy/Travellers can as well.

There are three basic positions on the ethnicity of Scottish Gypsy/Travellers and each one leads to a different explanation of Scottish Gypsy/Traveller inequality. Each also stands up to varying degrees of academic scrutiny. The first position actively denies the ethnicity of Scottish Gypsy/Travellers. It regards Scottish Gypsy/Travellers as something of a historical curiosity - a reminder of 'old Scotland' and the different groups that made up this supposed mythical and ancient land (Brian Adam, cited in McKinney 2003, p. 22). This position, I would argue, essentially pathologises Scottish GypsyTraveller culture and implies that Scottish Gypsy/Traveller identity is actually just a slightly older and archaic form of 'Scottishness', possibly connected to those people who suffered due to Fuadach nan Gaidheal, the Highland Clearances, 1790-1845 (Mackenzie 1991; Prebble 1969). As Rebecca McKinney has pointed out, this position does not help explain the current treatment of Scottish Gypsy/Travellers by the settled community which in turn does not explain the unequal status of Scottish Gypsy/Travellers in post-devolution Scotland (McKinney 2003, pp. 20-22). This kind of 'old Scotland' analysis, which seems prevalent, is a 'commonsense' reading of the situation. Despite this, however, the position carries little academic weight and texts justifying such analysis are very difficult, if not impossible, to find. The second position similarly denies that Scottish Gypsy/Travellers are an ethnic group but concedes that Scottish Gypsy/Travellers experience prejudice and discrimination. In consequence this position advances the idea that there are no substantive differences between Scottish Gypsy/Travellers and settled people. It tends to be an

case in Scotland is a vexed question and beyond the remit of this paper. I would only tentatively suggest that those individuals and families who have been involved in such cases and have either settled out of court or pulled out at some point during a case would need to be interviewed and their reasons gathered and analysed. 
upfront assimilationist position. 'Underneath it all', the argument goes, 'Gypsy/Travellers and settled people are all the same': in time, Scottish Gypsy/Travellers can be assimilated into settled Scottish society. The third position recognises Scottish Gypsy/Travellers as a distinct social and cultural group and suggests that there may be genuine tensions between, for example, nomadic and settled modes of existence but argues that these are better resolved or accommodated through being recognised rather than simply denied or criminalised (Bancroft, Lloyd and Morran 1996; Lloyd and Morran 1998). Importantly, the latter position out of the three is the only one that allows that there might be positive aspects to being a Scottish Gypsy/Traveller. Each of these analyses has immediate implications in terms of ethnicity and, as we have already seen, the debate about ethnicity and racism is not simply an academic dispute about the correct use of neutral or objective concepts. This is not just a question of semantics or legal foreplay: it strikes to the very core of how people make sense of the unequal status of Scottish Gypsy/Travellers and what remedies may be available to address this situation.

\section{ARguing THE CUltural AND Legal CASE FOR SCOTTISH GYPSY/TRAVELLER ETHNICITY}

It has been argued that most academic commentators tend to accept Scottish Gypsy/Traveller ethnicity fairly matter-of-factly, going against what might be termed a 'common sense' perspective. This might, of course, represent a failing in intellectual and critical thinking on the issue since it is usually assumed that Scottish Gypsy/Traveller ethnicity is so self-evident that it does not require more detailed discussion (Kenrick and Clark 1999, pp. 51-53; Okely 2004; Whyte 2001). It should not, however, imply that there is no

\footnotetext{
${ }^{9}$ The centrality of an assimilation strategy was made clear by the initial remit given to the first term of the Advisory Committee on Scotland's Travelling People (19711974): 'To keep the whole situation relating to "Scotland's Travelling People" under review over a three-year period, in particular to provide a bridge between the Travellers and the settled community with a view to achieving greater tolerance and understanding of each other's point of view, and in general to act as a focal point for the further consideration of the welfare of Travellers'. The Advisory Committee functioned in Scotland from 1971-1999, after nine terms of office, and it ended its life when 'mainstreaming equality' was being championed as the way ahead by the Scottish Executive on matters of inequality in Scotland.
} 
literature supporting the case for Scottish Gypsy/Traveller ethnicity. Anthropologists engaging with Scottish Gypsy/Travellers have tended to address questions of 'difference' vis-à-vis the various cultural traits and customs that confirm Traveller ethnic identity and separateness (Rehfisch 1958 1961; Rehfisch and Rehfisch 1975). More recently, other academics have engaged more directly with the question of Scottish Gypsy/Traveller ethnicity in the face of widespread 'common sense' opposition to the notion of Scottish Gypsy/Traveller ethnicity, despite the fact that there was never a strong academic case against Scottish Gypsy/Traveller ethnicity (Braid 2001; McKinney 2003, p. 19). These authors would all agree with the now 'retired' Advisory Committee on Scotland's Travelling People that:

Membership [of the group] through birth and descent confers the Traveller identity. Self-ascription and recognition from the wider group dictate who is, or is not, a Traveller... it [is] essential to actively combat and challenge stereotyping of Travellers and all forms of racism against them. (Scottish Executive 2000, pp. 28 -29-my emphasis).

It is commonly argued in the above academic analyses that Scottish Gypsy/Travellers are an ethnic group and this holds for commentators whether they accept Scottish Gypsy/Traveller ethnicity as self-evident or arrive at this point through a process of directly engaging with the appropriateness of using the term ethnicity with regard to Scottish Gypsy/Travellers. Moreover, this conclusion is reached whether researchers focus on academic, cultural or socio-legal definitions of ethnicity.

On the face of it, then, Scottish Gypsy/Travellers appear to be an ethnic minority group according to the Mandla $v$ Dowell Lee criteria of ethnicity. Certainly Scottish Gypsy/Travellers appear to fulfil the two 'essential characteristics' of ethnicity: 1) they have 'a long shared history' of which they are conscious as distinguishing them from other groups; and 2) they have a 'cultural tradition of their own'. This is in part why most academics have regarded Scottish Gypsy/Travellers as an ethnic group without much hesitation. Since these are the two 'essential characteristics' for ethnicity, however, they do merit deeper investigation and analysis. ${ }^{10}$ In any court case

${ }^{10}$ Due to space restrictions I am only concerned here with the two 'essential' characteristics. I am not concerned in this article with the other elements that Lord 
it is these two elements that will be fully assessed and largely determine the outcome of any ruling.

\section{1) Scottish Gypsy/Travellers: A long shared history?}

Mandla $v$ Dowell Lee makes it clear that this 'long shared history' is one of 'which the group is conscious as distinguishing it from other groups', and 'the memory of which is kept alive'. Importantly, a long shared history is not enough in and of itself. This history must be accompanied by a degree of group consciousness: the group must be aware of its difference from other groups as well as carry a surviving memory of its own history.

There is little doubt that Scottish Gypsy/Travellers have a 'long shared history'. The specifics and dynamics of that history are, however, more contentious (McCormick 1907; Rehfisch 1958, 1961; Vallee 1955). Most discussion involving nomadic groups focuses very quickly on the origins of the group. ${ }^{11}$ There is far less attention given to group 'history' than to group 'origins' or, more precisely, the debate about origins becomes the 'history' of the nomadic group in question. This is not something to be examined lightly and it occurs in almost every situation where there are nomadic/settled tensions. Most often the debate becomes one that attempts to distinguish between 'real' nomads (Gypsies or Romanies for example) and a group of supposed impostors or 'drop-outs' from settled society ('didikai' ('rough Travellers') and, more recently, New Age Travellers). This has been a central part of the debate about the nature of Scottish Gypsy/Travellers. Much weight is lent to the question, 'where do Gypsy/Travellers come from?' and the inference is that ethnicity is appropriate to some exoticised migrants but not to indigenous groups whose origins lie in their own failure to survive

Fraser suggested were 'relevant' in the Mandla v Dowell Lee criteria: see above and http://www.hrcr.org/safrica/equality/Mandla_DowellLee.htm

${ }^{11}$ For example, there has been a European-wide fixation with the origins of Roma or 'Gypsies' (Iovita and Schurr 2004, pp. 267-268). They are often pathologised because they are not 'natives' of the country where they are travelling or staying. Conversely, Scottish Gypsy/Travellers have often been pathologised because they are not 'real [exotic] Gypsies' (Okely 1983). Thus, whether a nomadic group is indigenous or not, the question of origins can be used in a flexible way to problematise nomadic peoples and deny ethnicity. This is a key point: see Clark and Campbell (2000) for a discussion of such issues in relation to Czech and Slovak Roma asylum-seekers in Britain post-1997. 
within the wider society (Okely 1983). Scottish Gypsy/Traveller ethnicity is refuted and replaced with ingrained pathology and the logic of this pathology suggests that Scottish Gypsy/Travellers are not a distinct ethnic group with their own culture but rather a social underclass with a deviant subculture or an 'undeveloped' and 'backward' grouping of ancient Scots who have somehow, due to their own failings, not embraced modernity. ${ }^{12}$

The counter to this process is the assertion that such questions are hardly unproblematic for non-Gypsy/Travellers. The question, 'where do Scottish Gypsy/Travellers come from?' may perhaps never be fully or even adequately answered but then neither will the questions such as 'where do English people come from?' or 'where do Welsh people come from?' The origins of Scottish Gypsy/Travellers are no more complex than the origins of either of these groups. They each have 'long shared histories' but these are constituted in fluid, complex and contradictory ways. The question of origins is often a key part in the construction of Scottish Gypsy/Travellers as an unwelcome 'invasion' and, in the wider British context, anti-Gypsy/Traveller prejudice can become a specific subset of anti-Scottish racism; this is obviously somewhat different to the dynamic in Scotland itself. Furthermore, since it constructs Scottish Gypsy/Travellers as unwelcome outsiders, the focus on origins often suggests that they do not have, or indeed deserve, any formal or substantive rights as citizens. This said, there is still good reason for addressing the origins question with regard to Scottish Gypsy/Travellers as it throws important light on the popular beliefs that Scottish Gypsy/Travellers are either dispossessed peasants (due to the Highland Clearances) or members of a 'backward' deviant subculture.

As indicated, the origins of the Scottish Gypsy/Traveller population remains disputed but there is a degree of common opinion that suggests Scottish Gypsy/Travellers have their roots in a Celtic, and possibly pre-Celtic, nomadic population in Scotland: 'In Scotland, too, the Tinker was known

\footnotetext{
${ }^{12}$ On this issue see Reid (1997, pp. 33-34) who, from a Scottish Gypsy/Traveller perspective, raises the notion that sometimes Gypsy/Travellers are valued as being original representatives of a traditional 'Scottish culture' rather than 'Gypsy/Traveller culture' in and of itself. This is especially true of folklorists according to Reid. This matter is also discussed in an important chapter by Okely (1997) on the political consequences of intellectuals looking at Gypsy ethnicity. In this chapter, Okely discusses her involvement in legal cases trying to determine ethnicity (1997, pp. 235-236).
} 
long before the advent of the Gypsies' (Fraser 1995, p. 296). There has been, historically, some inter-marriage and social/trading networks with the Roma, a nomadic population that, it is argued, migrated from India, through Egypt and through Eastern Europe (hence 'Gypsies' and 'Romanies') to Western Europe (Whyte 2001). Written evidence of their presence in Britain can be dated as 1505 in Edinburgh and is taken from an account written up by the then Lord High Treasurer of Scotland (Fraser 1995, pp. 111-112):

Item the xxij day of Aprile, to the Egiptianis, be the Kingis command, $x$ Franch crounis; summa vij li [£7]

The original Scottish nomadic population may have been supplemented at various times in Scottish history by dispossessed labourers and other marginalised people. Gradually this population developed a clear sense of its distinct social and cultural identity, an identity that was, and still is, held together by overt prejudice and discrimination from the settled community.

It is true that Scottish Gypsy/Travellers are quite distinct from recent Roma arrivals in Scotland, via government asylum dispersal schemes for example, because they are an indigenous nomadic group. While this may make them less 'exotic' than Roma in a racialised discourse, it does not make them any less distinct from the settled population. In this, Scottish Gypsy/Travellers are far from being unique. There are similar indigenous nomadic groups all over Europe, like Quinquis in Spain, the Tattere in Sweden and the Woonwagenbewoners in the Netherlands (Kenrick 1994, pp. 20-35; Liégeois 1987, pp. 17-18). In fact, Kenrick (1994, p. 34) identifies eight different indigenous nomadic groups across Europe as well as a number of others that have resulted from a degree of intermarriage between Romani people and indigenous nomadic groups. It bears emphasis that there is no good reason for saying that a nomadic group is less 'ethnic' or less 'true nomad' or less distinctive because it is indigenous rather than extraneous in origin.

One of the most common and deeply held misconceptions about Scottish Gypsy/Travellers in both Scotland itself and the rest of Britain is that they were a product of the Highland Clearances, 1790-1845. Scottish GypsyTravelers (note spelling) in the USA or indeed in Australia and Canada give the lie to this since many of them first went to the USA, Australia or Canada during the 'Clearances' and yet they have maintained a separate ethnicity, language and culture ever since (Lockwood and Salo 1994). There is also a large amount of other evidence pointing to the existence of Scottish Gypsy/Travellers in Scotland prior to the Highland Clearances, especially in 
places such as Kirk Yetholm (Brockie, 1884; Chambers, 1886; Fraser 1995; Lucas, 1882; Mayall 1988, pp. 111-112; Whyte 2001). This evidence offers some indication of what Scottish Gypsy/Traveller culture and identity was like prior to the Clearances. This is particularly pertinent since it provides at least an impression of the 'cultural stuff' that emigrant Scottish Gypsy/Travellers took with them to the USA and other destinations, including language. It also reminds us that part of the 'long shared history' of Scottish Gypsy/Travellers is a history of emigration.

\section{Emigration from Scotland}

According to the late Sir Angus Fraser (1995, p. 170), in Scotland so-called 'idle vagabonds', which in part included those people formerly known as 'Tinkers' or as they are now known, Scottish Gypsy/Travellers, were subjected to:

the threat of transportation 'into the West indies or elsewhere' in 1655 by a government ordinance during Cromwell's Protectorate, after the Generals of the military occupation has been appalled by the 'multitudes of Vagabonds, masterful beggars, [and] strong and idle persons' wandering over the country. Within ten years such possibilities for deportation were being exploited by ordinary citizens ... in 1715, eight border Gypsies - two men and six women - of the names Faa, Stirling, Yorstoun, Finnick (Fenwick), Lindsay, Ross and Robertson were despatched by the Glasgow magistrates to the Virginia plantations 'for being habite and repute gipsies, sorners, \&c' in fulfilment of the sentence to transportation which Jedburgh circuit court had pronounced on them even though the evidence on the other charge, of arson, has been very shaky.

Fraser's historical magnum opus and his precise use of primary historical data provides one of the few accounts of Scottish Gypsy/Traveller identity in the mid-Nineteenth Century and before. He is not alone, however, as F. H. Groome (1890-91) reported on the transportation of Scottish Gypsy/Travellers from Scotland to America in the pages of the Journal of the Gypsy Lore Society in the 1890s. Such sources, along with MacRitchie (1894) of course, provide key evidence of the existence of Scottish Gypsy/Travellers in Britain at this time and also as a group selected for deportation due to whom and what they were perceived to be. Some of this generation of Scottish Gypsy/Traveller emigrants went to America and 
Canada (Rehfisch and Rehfisch 1975, p. 279) but others stayed in Britain or went to other parts of the globe such as the West Indies or Australia. Some became sedentary due to effectively being slaves on the plantations, so-called 'indentured labour' as Williams (1944) has put it, but others continued a nomadic life and they continued to see themselves as, and be seen as, Scottish Gypsy/Travellers. There is a 'long shared history' of Scottish Gypsy/Travellers inside and outside of Britain from at least this point to the present day.

\section{Urbanisation}

The Scottish Gypsy/Traveller experience in Scotland and other parts of Britain, such as Liverpool and London, has changed significantly since the Second World War. Like the settled population, the Scottish Gypsy/Traveller population has urbanised over the past fifty years or so (Douglas 1997; Gentleman and Swift 1971, p. 20; Gentleman 1993). The Scottish Gypsy/Traveller population has undergone a profound transformation because of the decline of traditional rural-based economic activities, such as farm work and other occupations such as pearl-fishing (Neat 1998). It bears emphasis that this process was neither of the Scottish Gypsy/Travellers making nor within their power to prevent. This economic shift encouraged the urbanisation of many Scottish Gypsy/Travellers in Scotland and some migration to other parts of Britain and beyond. Most academic observers have identified the importance of this transformation (Kenrick and Clark 1999; Braid 2001). However, this process did not stop people being Scottish Gypsy/Travellers: it meant that they were Scottish Gypsy/Travellers in a new social and economic context that allowed for adaptation and the diversification of trades and employment activities that Scottish Gypsy/Travellers engaged in (Clark 2002, pp. 187-189).

When we look at the question of origins and numbers of Scottish Gypsy/Travellers in Britain and Scotland it becomes apparent that most popular stereotypes do not stand up to objective assessment. These notions, whether they are about the supposed origins of Scottish Gypsy/Travellers, or about their not being 'real' nomads, or about their 'swamping' particular areas, owe more to prejudice and fantasy than to reality. Objectively we can say that contemporary Scottish Gypsy/Travellers in Scotland are part of a nomadic community that has endured for centuries throughout the whole of Scotland. There has been substantial Scottish Gypsy/Traveller migration 
from Scotland and Britain since at least the period of the main Highland Clearances (1790-1845), if not before. In short, there is a long shared history.

\section{Group consciousness}

It is clear that Scottish Gypsy/Travellers have long had awareness of selfidentity and of 'difference' from the settled populations in both Britain and within Scotland itself (Rehfisch 1958; Reid 1997; Vallee 1955). Belonging to the category 'Scottish Gypsy/Traveller' was the defining feature of Scottish Gypsy/Travellers' lives. Settled people cannot 'become' Scottish Gypsy/Travellers, even if they marry into a Scottish Gypsy/Traveller family or begin to lead a nomadic way of life. This is not a 'lifestyle choice' that can be bought and sold or somehow 'worn'. This sense of profound difference between Scottish Gypsy/Travellers and settled people is widely evidenced in the plethora of literature and audio recordings held in the archives at the School of Scottish Studies at the University of Edinburgh. ${ }^{13}$ It is also evident in an increasing number of Scottish Gypsy/Traveller biographies and autobiographies (MacColl and Seeger, 1986; Robertson 1988, 1989; Smith 2002, 2003, 2005; Williamson 1990, 1994; Whyte 1986, 2000). The wider academic and policy debates around Scottish Gypsy/Traveller ethnicity have also raised awareness of the issue within the Scottish Gypsy/Traveller community itself (McKinney 2001, pp. 9-10; McKinney 2003). In this sense Scottish Gypsy/Travellers are becoming ever more conscious and 'politicised' regarding their 'long shared history' which 'distinguishes them from other groups'. The social and group boundaries are clearly 'known' and passed down from generation to generation and the memory of this shared history remains very much alive, now in written form as much as the longstanding oral tradition that Scottish Gypsy/Travellers continue to value a great deal. $^{14}$

\footnotetext{
13 The School of Scottish Studies archives can be viewed here: http://www.pearl.arts.ed.ac.uk/

${ }^{14}$ The work of the self-help Romany and Traveller Family History Society (RTFHS) is a case in point here. This organisation helps people with Gypsy and Traveller ancestors share knowledge within the communities concerned and find out more about their common histories, family connections, 'roots' and genealogies:http://website.lineone.net/ rtfhs/
} 


\section{2) Scottish Gypsy/Travellers: A cultural tradition of their own?}

Mandla v Dowell Lee makes it clear that a 'cultural tradition of its own' can include 'family and social customs and manners, often but not necessarily associated with religious observance' (my emphasis). There are a whole range of Scottish Gypsy/Traveller-specific family and social customs and manners. These include a specific 'Gypsy/Traveller economy' (Kenrick and Clark 1999; Clark 2002), 'matching' or arranged marriages, and a series of 'ritual boundaries' via pollution taboos broadly similar to those of Roma (Okely 2004, pp. 8-10; Rehfisch 1958, 1961; Rehfisch and Rehfisch 1975, p. 272). As Fraser summarises there was some 'mixing' between Scottish Gypsy/Travellers and Roma but the former 'held its own' (1995, pp. 296297, my emphasis):

In Scotland, too, the tinker [Scottish Gypsy/Traveller] was known long before the advent of the Gypsies, and this original population more than held its own with the newcomers. Little is known of the relations between them in the past, but there must have been a good deal of contact, including intermarriage, and the Gypsy stream broadened out. Many Scottish Travellers certainly share some Gypsy taboos (e.g. in regard to washing clothes and dishes in the same basin), while Romani words in their private language, 'the Cant', are pretty universal, alongside words from Gaelic and Scots and also from cant in its old sense (i.e. the secret jargon of the underworld, first recorded in the sixteenth century

In the case of Scottish Gypsy/Travellers I would argue that their cultural tradition and history is more specifically associated with nomadism than religion. This is a crucial point to consider. While Mandla v Dowell Lee suggests cultural traditions will often be associated with religion, it seems difficult to argue against the case that the cultural difference between nomadism and sedentary lifestyles is at least as distinctive as that associated with religious difference in other instances of ethnic plurality (McVeigh 1997: 15-17). This was an argument advanced by McVeigh in his report for the Irish Traveller ethnicity court case in 2000 (McVeigh 1999, pp. 26-27). In this report he quotes an Irish Traveller, Michael McDonagh, and his description of what it is to be nomadic. This perfectly captures what the cultural difference is: 
When Travellers speak of travelling, we mean something different from what country people [settled people] usually understand by it. ... Country people travel to get from A to B. But for Travellers, the physical fact of moving is just one aspect of a nomadic mind-set that permeates every aspect of our lives. Nomadism entails a way of looking at the world, a different way of perceiving things, a different attitude to accommodation, to work and to life in general. (1994, p. 95)

As with Irish Travellers, this disposition to travel does not confirm stereotypes about the alleged 'shiftlessness' or 'irrationality' of Scottish Gypsy/Travellers. Rather it illustrates the continuing commitment of most Scottish Gypsy/Travellers to an ideology and practice of nomadism, despite the legal difficulties attached to travel and movement in Britain and Scotland for them as an ethnic group after the passing of the Criminal Justice and Public Order Act 1994 (Kenrick and Clark 1999, pp. 57-58). This practice of nomadism is especially evident during the warmer summer months when the fairs are on and in winter a temporary shift into housing is not that uncommon. ${ }^{15}$ This psychological aspect of nomadic identity remains a key element in Scottish Gypsy/Traveller ethnicity. As Jess Smith (2003, p. 223), a Scottish Gypsy/Traveller who has long been settled in housing recently put it:

My travelling days never found the way back onto the road, because I travelled a different one ... However, as I said before, 'you can take the traveller out of the road but never take the road out of the traveller.' I believe my road is still there, finding new bends and campsites. Yes, of course they are all in my mind, but that's okay. As a storyteller and singer I share them with everyone.

However, the changing role of nomadism in Scottish Gypsy/Traveller experience is often used to support the idea of the redundancy of a specific Scottish Gypsy/Traveller economy, and, by implication, a 'diluting' of their ethnicity (Lomax, Lancaster and Gray 2000, pp. 38-52). Not only does this

${ }^{15}$ Indeed, there is historical precedent here. Rehfisch and Rehfisch (1975, p. 274) noted the trend that Travellers would often move into rented housing and other forms of 'brick and mortar' accommodation over the harsh winter months and travel again in the summer, much like the Gypsies and Travellers in Scandinavian countries would do (Hvenegård-Lassen and Wickström 1991). 
romanticise the past but it condemns and closes off the present and future. It suggests the loss of an assumed and mythological Arcadian past when Scottish Gypsy/Travellers had a function in society; forgetting that every cultural and occupational group is changed profoundly by urbanisation and sedentarisation. Seeing the urbanisation of Scottish Gypsy/Travellers only in terms of 'loss' denies the possibility that the economic base of nomadism might be adapted and developed in response to the new demands of the urban environment in positive ways, such as re-cycling, landscape gardening, market trading and so on. It also binds the issue of Scottish Gypsy/Traveller ethnicity completely to nomadism: it suggests that Scottish Gypsy/Travellers are an ethnic group because they are nomadic and they stop being an ethnic group when they stop being nomadic. Nomadism is a sufficient condition for a 'cultural tradition of their own' for Scottish Gypsy/Travellers but it is not, however, a necessary condition. Scottish Gypsy/Travellers remain Scottish Gypsy/Travellers after they become predominately sedentary and the best comparator for this process is the Roma population in Central and Eastern Europe. This population has been sedentary for generations since it was compulsorily sedentarised through Gypsy slavery in the Eighteenth and Nineteenth Centuries and, again, under communism in the Twentieth Century (Crowe and Kolsti 1991; Hancock 1987). Yet, the Roma remain a markedly distinct ethnic group in Central and Eastern Europe to the present day: indeed, they are targeted by racists because they are seen as Tsigane (Gypsy) (Bancroft 2005, pp. 100-101). There is little evidence of a de-ethnicisation process being attached to the end of nomadism in the case of the Roma. In fact, in many ways, since the early 1990s the opposite has been true and a new ethnic and cultural 'rebirth' is underway within the Roma populations across Central and Eastern Europe who are mobilising on a multitude of different economic, political and cultural fronts (Barany 2002, pp. 202-240). It is evident that Scottish Gypsy/Travellers have a cultural tradition that they can call their own and features such as nomadism, language, economy and social boundaries are important elements to this culture.

\section{CONCLUSION}

It is clear from this discussion that the concepts and language of 'race', ethnicity, identity and racism can be rather elusive and slippery. Such ideas are also complicated when drawn upon to make sense of the experience of Scottish Gypsy/Travellers. Equally, however, the issues of 'race', ethnicity, identity and racism are complicated when used to make sense of the 
experiences of any racialised minority group in the $21^{\text {st }}$ Century (Gilroy 2000, pp. 1-8). As we have seen, ethnicity is not dependent on the reified pseudo-biological concept of 'race' and is increasingly distanced from 'race' as a social construct (Banton 1998; Miles and Brown 2003). The Mandla v Dowell Lee decision provides the benchmark for a legal assessment of ethnicity in a court of law in Britain. While there are certainly differences between defining features of Scottish Gypsy/Traveller identity and, say, African Caribbean identity, there are equally differences between the defining features of African Caribbean and Chinese or South Asian identity. The crux of the matter is this: ethnicity is increasingly seen to be fluid, negotiated and heterogeneous and there are no longer any simple and clearcut definitions of it (Geyer 1996). This is not to suggest there are no foundations at all when it comes to 'naming' ethnicity. As discussed during this article, Lord Fraser's judgement in Mandla v Dowell Lee certainly secures a foothold in terms of the legal dimensions and there are compelling reasons for including Scottish Gypsy/Travellers among other ethnic minority groups who are protected by the Race Relations Act 1976 (as amended 2000).

In the introduction to this article it was noted that Scottish Gypsy/Travellers are 'to be regarded' as an ethnic group in Scotland by both the Scottish Parliament and Scottish Executive until a test case in a court of law clarifies matters. Since 2000-01 this fact has not been contested in any meaningful way and it is now the case that Gypsy/Traveller children, if they choose, can tick their own box in school Census counts. It logically follows from this that they can, in principle, experience racial discrimination. As it stands Scottish Gypsy/Travellers are undoubtedly as much an 'ethnic group' as any other which is currently protected by the Race Relations Act 1976 (as amended 2000) despite the fact that at the moment they generally lack the substantive protection of the Act in the Scottish context. It follows that Scottish Gypsy/Travellers in Scotland or Britain can experience racial discrimination which is not dissimilar to that experienced by all the minority ethnic groups currently protected by race relations legislation, including English Gypsies and Irish Travellers. Whether they do experience racism is, of course, a matter for the police and courts to address in the individual cases that occur rather than any academic analysis. The next stage of the process will, eventually, see a test case come before the Scottish courts and complete its journey through the legal system. Only when this happens will the sociolegal status of Scottish Gypsy/Traveller ethnicity be firmly decided. 


\section{ACKNOWLEDGEMENTS}

I wish to thank the Commission for Racial Equality in Scotland who funded the research that this paper is based on, in particular Kathleen Bolt and Stuart Robertson. I also wish to acknowledge two important papers that helped me write this article: the expert report 'Irish Travellers and Ethnicity' written by my colleague Dr. Robbie McVeigh for the case of Kiely and Others - $v$ Allied Domecq and Others (No CL 950275-79) in 2000 and also the judgement delivered in this landmark case by his Honour Judge Goldstein on 29 August 2000 in the central London County Court. Both of these papers helped shape my thoughts and arguments. I would also like to thank and acknowledge the constructive comments from the two anonymous referees as well as the editor of Scottish Affairs, Professor Lindsay Paterson. This article is dedicated to Miss R. T. McPhee and family.

\section{REFERENCES}

Acton, T. (Ed.). 1997. Gypsy Politics and Traveller Identity University of Hertfordshire Press.

Acton, T. and Mundy, G. (Eds.). 1997. Romani Culture and Gypsy Identity University of Hertfordshire Press.

Alexander, M. 2005. 'The tinker's tale', The Courier and Advertiser, Friday July 1. p6.

Bancroft, A. 2005. Roma and Gypsy/Travellers in Europe: modernity, race, space and exclusion Aldershot: Ashgate Press.

Bancroft, A., Lloyd, M. and Morran, R. 1996. The Right to Roam: Scotland's Travelling People Edinburgh: Save the Children.

Banton, M. 1998. (Second edition) Racial Theories Cambridge: Cambridge University Press.

Barany, Z. 2002. The East European Gypsies, Cambridge: Cambridge University Press.

Barker, M. 1981. The New Racism London: Junction Books.

Barth, F. 1969. 'Introduction' in Barth, F. (ed.) Ethnic Groups and Boundaries the Social Organisation of Culture Differences. London: George Allen and Unwin.

BBC 1995. EX's - Tales from the Tarmac, television broadcast (30 minutes) first aired on 07-03-1995 on BBC2, Scotland. 
Beckett, J. and Bogie, M. 1998. 'Travellers and the law in Scotland', in Judicial Review, Number 21: 21-35. Edinburgh: W. Green and Son.

Blum, A. 2001. 'Recognition as protection/recognition as threat: understanding the link between minority rights and ethnic hostility', Nationalism and Ethnic Politics, 7(2): 95-124.

Braid, D. 1997. 'The Construction of identity through narrative: folklore and the Travelling People of Scotland', in T. Acton and G. Mundy (Eds.) Romani Culture and Gypsy Identity Hatfield: University of Hertfordshire Press.

Braid, D. 1999. ' Our stories are not just for entertainment': lives and stories among the Travelling People of Scotland' in M. Read McDonald (Ed.) Traditional Storytelling Today: an international Encyclopaedia London: FitzroyDearborn.

Braid, D. 2002. Scottish Traveller Tales: lives shaped through stories, Mississippi: University of Mississippi Press.

Brockie, W. 1884. The Gypsies of Yetholm: historical, traditional, philological, and humorous Kelso: J. and J.H. Rutherfurd.

Burleigh, M. and Wippermann, W. 1991. The Racial State: Germany 1933-1945 Cambridge: Cambridge University Press.

Chambers, W. 1886. Exploits and Anecdotes of the Scottish Gypsies Edinburgh: William Chambers (private press).

Clark C. 1999. 'Race', Ethnicity and Social Security: The Experience of Gypsies and Travellers in Britain'. Journal of Social Security Law 6(4):186-202.

Clark, C. 2001. 'The United Kingdom: England, Northern Ireland, Scotland and Wales', in Save the Children Fund Denied a Future? The Right to Education of Roma/Gypsy and Traveller Children, London: Save the Children Fund, pp206-301.

Clark, C. 2002. 'Not just lucky white heather and clothes pegs': putting European Gypsy and Traveller economic niches in context' in Fenton, S. and Bradley, H. (eds.) Ethnicity and Economy: Race and Class Revisited, Basingstoke: Palgrave.

Clark, C. 2004. 'Ethnicity, the law and Gypsy/Travellers in Scotland: which way now?' in C. Pronai and S. Salo (Eds.) Ethnic Identities in Dynamic Perspectice: Proceedings from the Gypsy Lore Society Conference 2002 Budapest: Gondolat and Ethnic and National Minority Studies Institute of the Hungarian Academy of Sciences.

Clark, C. and Campbell, E. 2000. “Gypsy Invasion': a critical analysis of newspaper reaction to Czech and Slovak Romani Asylum-seekers in Britain 1997.'

Romani Studies (continuing the Journal of the Gypsy Lore Society), Series 5, 10 (1):23-47. 
Clark, C. and Dearling, A. 2000. 'Ethnicity, nomadism, and 'Traveller' identity: in pursuit of common ground'. Social Work in Europe 7 (1):42-50.

Clark, C., Smart, H. and Titterton, M. 2003. 'A literature review of the health of Gypsy/Traveller families in Scotland: the challenges for health promotion', Health Education 103(3): 156-165.

Clarke N., Egon, K. and Wake, M. 1998. Living on the Edge of Your Town, London: Bridge Housing Association.

Crawford, A. 2003. 'Gypsies slam 'middle class' race watchdog' The Sunday Herald 14 September 2003.

Crowe, D. and Kolsti, J. 1991. The Gypsies of Eastern Europe London: M. E. Sharpe.

Dawson, R. 2002. Scottish Traditional Travelling Families Derby: Robert Dawson Publications.

Dawson, R. and Smith, J. 2001. The Scottish Traveller Dialects Derby: Robert Dawson Publications.

Douglas, A. 1997. Local Authority Sites for Travellers Edinburgh: Scottish Office Central Research Unit.

Douglas, S. 1985. The King O' the Black Art: a study of the tales of a group of Perthshire Travellers in their social context $\mathrm{PhD}$ thesis, Stirling: University of Stirling.

Douglas, S. 1987. The King O' the Black Art: and other folk tales Aberdeen: Aberdeen University Press.

Douglas, S. 2002. 'Travellers' Cant in Scotland' in J. M. Kirk and D. P. O Baoill (Eds.) Travellers and their Language: Belfast studies in language culture and politics 4 Belfast: Queens University Belfast.

Fraser, A. 1995. (Second edition) The Gypsies Oxford: Blackwell.

Fredrickson, G. M. 2002. Racism: a short history Princeton and Oxford: Princeton University Press.

Gentleman, H. 1993. Counting Travellers in Scotland: the 1992 picture Edinburgh: Scottish Office Central Research Unit.

Gentleman, H. and Swift, S. 1971. Scotland's Travelling People Edinburgh: HMSO.

Geyer, F. 1996. 'Introduction - Alienation, ethnicity and postmodernism: from here to postmodernity' in F. Geyer (Ed.) Alienation, Ethnicity and Postmodernsim Westport, Connecticut: Greenwood Press.

Gilroy, P. 2000. Between Camps: nations, cultures and the allure of race London: Penguin. 
Groome, F. H. 1890-91. 'Transportation of Gypsies from Scotland to America', Journal of the Gypsy Lore Society (1)2: 60-62.

Hancock, I. F. 1986. 'The Cryptolectal Speech of the American Roads: Traveler Cant and American Anglo-Romani’ American Speech Tuscaloosa, AL 61.

Hancock, I. F. 1987. The Pariah Syndrome: An account of Gypsy Slavery and Persecution Ann Arbor: Karoma.

Hutchinson, J. and Smith, A. (Eds.) 1997. Ethnicity Oxford: Oxford University Press.

Huttenbach, H. R. 1991. 'The Romani Pořajmos: the Nazi genocide of Gypsies in Germany and Eastern Europe'. In D. Crowe and J. Kolsti (eds.) The Gypsies of Eastern Europe, New York: M.E.Sharpe Inc.

Hvenegård-Lassen, K. and Wickström, K. P. 1991. Gypsies and Travellers in Denmark Copenhagen: Minoritets Studier Bibliotek. pp1-19.

Jenkins, R. 1999. Rethinking ethnicity: arguments and explorations London: Sage.

Jordan, E. 1998. Travellers in Scottish schools Unpublished PhD Thesis Edinburgh: Heriot Watt University.

Jordan, E. and Padfield, P. 2003. 'Education at the margins: outsiders and the mainstream' in T.G.K. Bryce and W. M. Humes (Eds.) Scottish Education: Post-Devolution (Second edition) Edinburgh: Edinburgh University Press.

Kenrick, D. and Clark, C. 1999. Moving On: the Gypsies and Travellers of Britain Hatfield: University of Hertfordshire Press.

Kenrick, D. 1994. 'Irish Travellers: A Unique Phenomenon in Europe?' in M. McCann, S. Ó Síocháin and J. Ruane (Eds.) Irish Travellers: Culture and Ethnicity Belfast: Institute for Irish Studies and the Anthropological Association of Ireland.

Liégeois, J. P. 1987. Gypsies and Travellers: Socio-cultural data, Socio-political data. Strasbourg: Council for Cultural Co-operation.

Lloyd, M. and Morran, R. 1998. Failing the Test Edinburgh: Save the Children.

Lloyd, G., Stead, J., Jordan, E. and Norris, C. 1999. 'Teachers and Gypsy Travellers', Scottish Educational Review 31 (1): 48-65.

Lockwood, W. and Salo, S. 1994. Gypsies and Travelers in North America: an annotated bibliography Cheverly: GLS Publications.

Lomax, D., Lancaster, S. and Gray, P. 2000. Moving On: A survey of Travellers' views Edinburgh: The Scottish Executive Central Research Unit.

Lucas, J. 1882. The Yetholm history of the Gypsies Kelso: J. and J. H. Rutherfurd, 
MaColl, E. and Seeger, P. 1986. Till Doomsday in the Afternoon: the folklore of a family of Scots Travellers, the Stewarts of Blairgowrie Manchester: Manchester University Press.

MacKenzie, A. 1991. The History of the Highland Clearances Mercat Press.

MacRitchie, D. 1894. Scottish Gypsies under the Stewarts Edinburgh: D. Douglas.

Maan, B. 1992. The New Scots: the story of Asians in Scotland Edinburgh: John Donald publishers.

McAllister, J. B. 2005. Remembering who I am Stirling: privately published poetry collection, p1-19.

McCormick, A. 1907. The Tinkler-Gypsies of Galloway Dumfries: J. Maxwell and Sons.

McDonagh, M. 1994. 'Nomadism in Irish Travellers' Identity' in M. McCann, S. Ó Síocháin and J. Ruane (Eds.) Irish Travellers: Culture and Ethnicity Belfast: Institute for Irish Studies and the Anthropological Association of Ireland.

McKinney, R. 2001. Different Lessons: Scottish Gypsy/Travellers and the future of Education Edinburgh: Scottish Travellers Consortium.

McKinney, R. 2003. 'Views from the margins: Gypsy/Travellers and the ethnicity debate in the new Scotland' Scottish Affairs no 42: 13-31.

McVeigh, R. 1997. 'Theorising sedentarism: the roots of anti-nomadism' in T. Acton (Ed.) Gypsy Politics and Traveller identity Hatfield: University of Hertfordshire Press.

McVeigh, R. 1999. Irish Travellers and Ethnicity Expert witness report for Kiely and Others -v- Allied Domecq and Others London: Commission for Racial Equality.

Mayall, D. 1988. Gypsy/Travellers in Nineteenth Century Society Cambridge: Cambridge University Press.

Miles, R. and Brown, M. 2003. (Second edition) Racism London: Routledge.

Morris, L. 1994. Dangerous Classes, London: Routledge.

Murray, C. 1990. The Emerging British Underclass, London: Institute of Economic Affairs.

Neat, T. 1998. The Summer Walkers Edinburgh: Canongate Press.

Nicolson, S. 2005. 'Gipsies in land 'grab' demand', The Scottish Daily Mail Wednesday June 22.

Okely, J. 1983. The Traveller-Gypsies Cambridge: Cambridge University Press. 
Okely, J. 1997. 'Some political consequences of theories of Gypsy ethnicity: the place of the intellectual' in James, A., Hockey, J. and Dawson, A. (eds.) After Writing Culture: epistemology and praxis in contemporary anthropology London: Routledge.

Okely, J. 2004. Scottish Travellers and Ethnicity, unpublished expert witness report commissioned by The Commission for Racial Equality (Scotland), Edinburgh: CRE.

Prebble, J. 1969. The Highland Clearances London: Penguin.

Reid, W. 1997. 'Scottish Gypsies/Travellers and the folklorists' in T. Acton and G. Mundy (eds.) Romani Culture and Gypsy Identity Hatfield: University of Hertfordshire Press.

Rehfisch, F. 1958. The Tinkers of Perthshire and Aberdeenshire, unpublished MA thesis, The School of Scottish Studies, University of Edinburgh.

Rehfisch, F. 1961. 'Marriage and the elementary family among Scottish Tinkers', Scottish Studies 5: 121-147.

Rehfisch, A. and Rehfisch, F. (1975) 'Scottish Travellers or Tinkers' in Rehfisch, F. (ed.) 1975. Gypsies, Tinkers and other Travellers London: Academic Press.

Robertson, S. 1988. Exodus to Alford Nairn: Balnain Books.

Robertson, S. 1989. Nyakim's Windows Nairn: Balnain Books.

Save the Children Fund. 1995. Travellers in Scotland Dunfermline: Save the Children.

Scottish Executive, The. 2000. Advisory Committee on Scotland's Travelling People: the ninth term report 1998-1999 Edinburgh: Scottish Executive.

Scottish Parliament, The. 2000. Equal opportunities committee official report, meeting 13, 23 May 2000.

Scottish Parliament, The. 2001a. Inquiry into Gypsy Travellers and Public Sector Polices Volume 1. Edinburgh: The Scottish Parliament.

Scottish Parliament, The. 2001b. Inquiry into Gypsy Travellers and Public Sector Policies Volume 2. Edinburgh: The Scottish Parliament.

Scottish Parliament, The. 2002. 'US State department highlights Scottish Parliament's work on Gypsy Travellers'. Committee News Release. Edinburgh: The Scottish Parliament. $\mathrm{http} / / /$ www.scottish.parliament.uk/S1/whats happening/news-02/ceq102001.htm 
Shams, S. 2004. The Kurds in Iran: a history of the present. A speech given at a public meeting at the House of Commons, London on 15 July 2004. Available online at http://www.pdk-

iran.org/english/doc/A\%20forgotten\%20struggle/The\%20Kurds\%20in\%20Iran $\% 20-\% 20 \mathrm{a} \% 20$ history\%20of\%20the \%20present.htm

Simpson, A. 2005. 'Anger as Police go soft on Gypsies', The Scottish Daily Mail Thursday June 16.

Smith, J. 2002. Jessie's Journey: Autobiography of a Traveller Girl Edinburgh: Mercat Press.

Smith, J. 2003. Tales from the Tent: Jessie's Journey Continues Edinburgh: Mercat Press.

Smith, J. 2005. Tears for a Tinker: Jessie's Journey Continues Edinburgh: Mercat Press.

Stewart, S. 2002. 'Cant: A Scottish Traveller's Perspective' in J. M. Kirk and D. P. O Baoill (Eds.) Travellers and their Language: Belfast studies in language culture and politics 4 Belfast: Queens University Belfast.

Vallee, F. G. 1955. The Tinkers of Scotland - report on a pilot study. Unpublished thesis, Edinburgh: School of Scottish Studies, Edinburgh University. 51 pp.

Williams, E. 1944. Capitalism and Slavery Carolina: University of North Carolina Press.

Williamson, D. 1990. May the Devil Walk Behind Ye! Scottish Traveller Tales Edinburgh: Canongate Press.

Williamson, D. 1994. The Horsieman: memories of a Traveller 1928-1958 Edinburgh: Canongate Press.

Whyte, B. 1986. The Yellow on the Broom London: Futura Publications.

Whyte, B. 2000. Red Rowans and Wild Honey Edinburgh: Birlinn.

Whyte, D. 2001. Scottish Gypsies and other Travellers: a short history Blackwell, Alfreton.

July 2005 
Scottish Affairs, no.45, autumn 2003 